\title{
Berichtigungen.
}

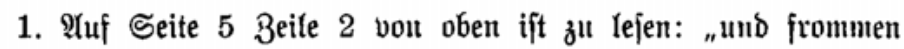

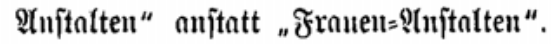

2. Ta auf Seite 1-72 an zutreffender Stelle noch bie §§ ber alten Civil=\$rozejorbunt angezogen find, jo wirb gebeten, unumegr

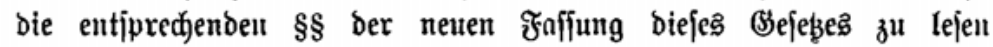
unto zwar:

\section{Seite Beile}

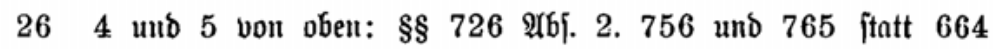

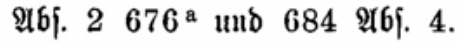

\begin{tabular}{|c|c|c|c|c|c|}
\hline 31 & 15 & " & " 850. & ftatt & 749 . \\
\hline 41 & 23 & $"$ & " $485-494$ & $"$ & $447-455$ \\
\hline 48 & 6 & $"$ & " 811 & $"$ & 715. \\
\hline 50 & 16 & $"$ & 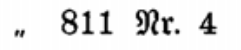 & $"$ & $715 \mathfrak{R r} .5$. \\
\hline 63 & 18 & " unten & " $794 \mathfrak{N r} .1$ น. 2 & $2 "$ & 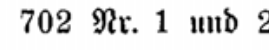 \\
\hline 71 & 4 & " oben & " 935 и. f. & $"$ & 814 น. f. \\
\hline
\end{tabular}

